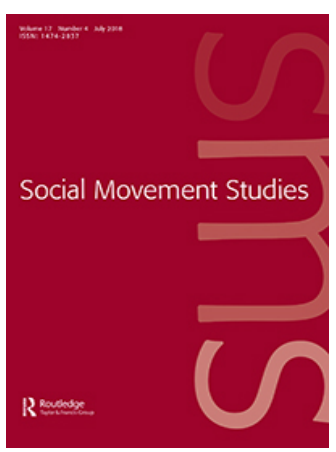

Social Movement Studies

\title{
Knowledge co-production with social movement networks. Redefining grassroots politics, rethinking research
}

\section{Alberto Arribas Lozano}

To cite this article: Alberto Arribas Lozano (2018) Knowledge co-production with social movement networks. Redefining grassroots politics, rethinking research, Social Movement Studies, 17:4, 451-463, DOI: $10.1080 / 14742837.2018 .1457521$

To link to this article: https://doi.org/10.1080/14742837.2018.1457521

曲 Published online: 28 Mar 2018.

Submit your article to this journal $\pi$

ЦIll Article views: 673

Q View related articles ¿

View Crossmark data \lceil

Citing articles: 2 View citing articles ¿ð 


\title{
Knowledge co-production with social movement networks. Redefining grassroots politics, rethinking research
}

\author{
Alberto Arribas Lozano \\ Society, Work and Development Institute, University of the Witwatersrand, Johannesburg, South Africa
}

\begin{abstract}
Drawing on ethnographic research with social movement networks in Spain, this article explores the challenges and possibilities of research collaboration. My project focused on the emerging logics and practices of collective action, the ongoing re-definition of grassroots politics. The engagement with social movements as reflexive communities - not simply objects to be studied, but subjects actively producing their own analysis and explanations, their own'knowledge-practices' - deeply transformed the in-fieldwork encounter. Through a series of co-analysis workshops, designed and implemented together with the research subjects/collaborators, this research became an open-ended dialogue of reflexivities. The shift from working on social movements to working and thinking together with social movement activists as co-researchers produced new scholarly knowledge, advancing our understanding of contemporary collective action, while simultaneously making research useful for the activists. Moreover, locating epistemic and methodological questions at the centre of the project, I addressed salient debates in social science, exploring collaborative frameworks in order to problematize traditional forms of knowledge production and validation.
\end{abstract}

\section{ARTICLE HISTORY}

Received 15 March 2017

Accepted 7 March 2018

\section{KEYWORDS}

Collaborative ethnography; social movements;

knowledge-practices; epistemic partners; grassroots politics; coanalysis workshops; research collaboration

As scholars working with social movements, what does it entail to do research with subjects who are (often) producers of expert knowledge themselves? What ethical, epistemic and methodological questions, and challenges, arise in the engagement with movement networks that operate as reflexive communities, that understand and conduct research, broadly conceived, as a key element of their daily praxis?

In this article, I underline the analytical role of social movement activists, stressing how they collectively create and mobilize knowledge of various types as a fundamental dimension of their political work. I also reflect upon the impact that recognizing (taking seriously) the role of activists as knowledge producers may have on the study of contemporary collective action, advocating for the exploration of research collaboration with social movements.

Literature has portrayed movement networks as cultural laboratories that 'pose new problems and questions and invent and test new answers' (Melucci, 1989, p. 208) in relation to the most diverse societal challenges. Scholars focusing on the 'cognitive praxis' of social movements have emphasized its impact in the generation of alternative technical and scientific expertise, a key element for the constitution and reconstitution of the scientific enterprise itself (Eyerman \& Jamison, 1991). Along 
these lines, Laurence Cox has claimed that, 'sociology's most creative moments have been those in which it engaged strongly with the knowledge produced by social movements' (2014, p. 966), and has encouraged sustained dialogue with activist organizations as a source of theoretical, epistemic and methodological innovation. Similar calls for understanding social movements not simply as objects to be studied, but as subjects actively producing their own analysis and explanations, have been articulated around the notion of movements 'knowledge-practices', intellectual interventions shaped by political activists involved in 'analysing, envisioning and elaborating new ways of knowing and being in the world' (Casas-Cortés, Osterweil, \& Powell, 2008, p. 28).

This does not mean that all social movements are devoted to 'knowledge-practices', nor does it imply that social movements that do operate as epistemic communities focus exclusively on cognitive work; activism is multidimensional: emotion, action and thought intertwine in praxis. My argument is that within ethnographic settings populated by this type of actor it is simply too arrogant, or too naïve, to try to maintain the fiction that the scholar is the only one invested with the authority and expertise for complex analysis and interpretation. Hence, research projects must move towards the articulation of a collaborative encounter between 'epistemic partners' (Holmes \& Marcus, 2008, p. 84), an open-ended dialogue of reflexivities for the co-production of knowledge.

Drawing on my PhD research, undertaken between 2008 and 2014 with activist networks in Spain, this article will illustrate both the possibilities and the complexities of research collaboration with social movements. Problematizing the traditional relation of the informant providing raw data to the 'academic-expert', collaborative methodologies advance a different politics of knowledge production (Arribas Lozano, 2018; Lassiter, 2005), promoting the joint design and implementation of the research project together with our research subjects-collaborators. Ideally, the questions to be addressed, the goals to be accomplished, the methods to be used, the production and interpretation of data, and the dissemination of outputs, are defined and reassembled through in-fieldwork negotiation. However, as I intend to do here, it is necessary to move away from normative and celebratory accounts of collaboration, and to thicken and ground the debate by analysing actual collaborative projects, whether successful or not.

My research explored the emerging logics and practices of collective action. I developed my project with the Network of Offices for Social Rights - Oficinas de Derechos Sociales (ODSs), analysing how and why movement participants were redefining their political imaginaries and practices, their narratives, organizational forms and repertoires of action. Hence, I did not focus on a singular episode of contention, but on the diachronic transformation - the reshaping - of grassroots politics. In this sense, my work operated as a sociology of emergences (Santos, 2014), the analytical anticipation of something that was yet to be defined.

The research began in a very conventional fashion; initially there were no common purpose, questions nor explorations; however, it shifted along the fieldwork encounter, becoming collaborative during its implementation. Fieldwork stretched over five years, a period divided into two differentiated phases. The first one began in May 2008 and lasted until February 2011, including episodes of participant observation in network meetings, protest events and daily activities, as well as 31 ethnographic interviews with activists from ten nodes of the network located in seven cities: Madrid, Barcelona, Zaragoza, Seville, Terrassa, Malaga and Pamplona/Iruña. ${ }^{1}$ The second phase, reaching until May 2012, was characterized by a 'collaborative turn', the articulation of a different type of in-fieldwork engagement in which the activists had a direct role in defining the research questions and methods: what knowledge should be produced, how and for what purposes. This collaborative turn materialized in a series of co-analysis and co-conceptualization workshops jointly designed and carried out with the members of the network.

The ODSs promoted grassroots self-organization against precarity, trying to build alliances - and beyond, some sort of what they called mestizo politics - between local and migrant communities affected by the intensifying precaritization of life. I decided to work with this network, first, due to the fact that the activists participating in the ODSs shared the determination to critically reconfigure their own political practices; second, because of their strong connection with knowledge production. ${ }^{2}$ 
As I will explain later, these activists understood collective deliberation and militant research as central to the transformation of praxis; this network used, 'political practice as an intensifier of thought, and analysis as a multiplier of the forms and domains for the intervention of political action' (Foucault, 1983, p. xiv). At the same time, the activists' critical self-reflexivity, their particular relation to knowledge-practices, played a crucial role in facilitating the articulation of research collaboration in my project. These two elements, the methodological dimension of my work, and the ethnographic case study on the transformation of collective action, intertwine in this article.

First, I briefly introduce the activist network in which I conduced fieldwork, the Network of Offices for Social Rights - ODSs. Second, I explain the key role that 'knowledge-practices' played in the political praxis of the network. Then, I outline the characteristics of research collaboration, emphasizing the opportunity to advance scholarly knowledge while simultaneously making research useful for the research subjects-collaborators. Finally, I illustrate how collaboration played out in my project, describing the 'collaborative turn' and the co-analysis workshops that took place during the fieldwork encounter.

\section{The ODSs and the redefinition of grassroots politics}

The Network of Offices for Social Rights was created in the mid-2000s within activist communities that prior to that moment had already been working and thinking together for more than a decade in multiple local, national and trans-European grassroots initiatives. They had always posed a profound critique of 'old politics' - political parties, institutional practices, major trade unions, logics of representation, and so on. However, and this was fundamental for my research, through that period of building and sharing political horizons and practices, reflections and common notions, and affect and memories developed in/through the struggle (action, meaning and emotions) these activists had also become increasingly critical of many elements of movement politics - including their own.

They problematized the small radical militant milieus, highly self-referential, and mostly populated by white, middle-class, graduate and urban activists. According to the network members, these spaces had turned into an inward-looking alternative subculture, based on symbolic and discursive radicalism, with no clear sense of direction, and without actual capacity for social transformation. Taking as a point of departure this criticism, that was also a self-critique, they set out to explore novel possibilities for grassroots political action. How to forge new solidarities? How to rethink political organization in highly individualized and fragmented contexts? How to re-imagine the coordinates and the horizon of political activism? In this sense, experimentation became a constitutive element of the network; Pantxo, ${ }^{3}$ one of the ODSs members in Barcelona, claimed that for them, 'the programmatic dimension is linked to the reinvention of the organizational forms and the redefinition of the ways of doing politics' (interviewed 25 October 2010).

This logic of experimentation nourished the emerging logics and practices of collective action: not a ready-made programme but an open imagination, what is coming, what - as stated by the activists themselves - we are still learning to name. In their collective effort to imagine and embody other ways of doing politics they talked about a politics of the encounter, a politics of listening, a politics of the artisan, a politics of daily life in which the 'common' that underpins and sustains collective action was not a given (based on predefined identity or ideology) but had to be produced and reproduced in and through the struggles by thinking and working together with other actors, producing meaning and organization with them. This was the proposal put forward by the network; a relational and process-oriented paradigm in which the activists and their organizations were not conceived of as experts framing the conversation. Rather, they had to decentre themselves, in a productive tension that closely resembles the one described in this article between researcher and research subjects.

How can these emerging assemblages be approached in research? How to grasp these messy configurations while they are being formed and deployed? According to Bruno Latour (2005), within this kind of situations, rather than attempting to impose some (disciplinary) order a priori, the researcher ought to follow the actors as they elaborate their own maps of concepts, relations and explanations, 
the moving borders of their own fields of action. Following the actors, paying special attention to the micro-political dimension -the making - of new meanings, subjectivities and practices, my project studied how collective action was being re-imagined and re-created.

Unexpectedly, my last year of fieldwork overlapped with the massive pro-democracy and anti-austerity mobilizations unleashed across the country since May 2011, the so-called '15 M Movement', the most important and innovative process of grassroots collective action in Spain in the last three decades (Arribas Lozano, 2015). To a large extent, although on a much bigger scale, the $15 \mathrm{M}$ embodied the ways of doing politics that the members of this community of activism had been testing over the last years, somehow confirming their insights. Both the ODSs and the $15 \mathrm{M}$ shared the principles of political experimentation, self-organization and direct action; the imagination and the making of a post-ideological grassroots politics (never to be confused with a cynical anti-politics); the materialization of the politics of the encounter, the search for openness and heterogeneity (the gathering of the bodies in the squares, the multiplicity of conversations and projects giving rise to a new political subject); the rejection of traditional political actors, including existing social movement networks and organizations; or the distributed network as the key organizational form, ${ }^{4}$ giving shape to a complex topology of entangled circuits of solidarity (exponentially bigger in the context of the $15 \mathrm{M}$ due to the use of social media). Many of these ideas, proposals, images and metaphors, which I had been analysing in my study of the Network of Offices for Social Rights as 'emerging', suddenly crystallized in the new scenario as the common sense of protest. As a result of their reflexive self-critique of traditional activism and their experimental ethos, these activists had anticipated what was coming.

\section{Movement networks as reflexive communities}

The second key feature of the ODSs was its distinctive relation to knowledge-practices. The members of this network understood and employed collective reflection and analysis, militant research, political experimentation and social movement formation, as concurrent dimensions of the same process. The production and mobilization of knowledge were central elements of their political praxis, never considered as a separate moment (an accessory) from 'real' political action.

The ODSs sought to forge virtuous cycles from practice to theory to practice. Through critical collective thinking and doing within the network, as well as with others - the politics of the encounter, the politics of listening, the Zapatista 'asking, we walk'- the activists triggered open-ended spirals of action-reflection-action, collectively producing new reflexivity (second-order reflexivity) and thence more creative possibilities for thought and action (Villasante, 2012). For the network members, collective deliberation and knowledge production were productive at different levels, enhancing common practice and informing new action. First, these elements were crucial in the struggle to define and redefine what was thinkable and what was possible (the limits of the imagination and praxis) in a particular context. Second, they would facilitate decision-making regarding instrumental and strategic actions, mobilizations, campaigns, alliances, and so forth - that will in turn generate new waves of collective analysis. Finally, they were a driving force for political innovation, guiding the (often experimental) transformation of movements' repertoires of contention, discourses, modes of organization, etc.

The cognitive praxis of the ODSs merged sociological and political imagination. The activists took their own lived experiences as the point of departure for reflection - a process that happened to be crucial, for instance, to start theorizing and writing about the multiple dimensions of precarity/ precaritization. However, the insights emerging through this process were constantly put in dialogue with other types of knowledge, bringing together political/militant knowledge, technical/academic knowledge and popular/subaltern expertise, in order to understand the structural dynamics and the wider social transformations that affected (and to some extent, determined) such lived experiences.

For this purpose, they regularly organized workshops and seminars which combined: movement knowledge collectively produced and embedded in practices of contention; knowledge produced through the collective reflection on the activists' lived experiences; and finally, the scholarly knowledge of activist academics and other intellectuals aligned with social movements. Another defining 
characteristic of these seminars and workshops was its international scope. Although the practices of the ODSs responded to the particularities of the contexts in which they were rooted, the discussions always included international networks and organizations, intellectuals and activists (mostly, but not only, from Latin America and Europe). In this sense, knowledge of various types was always on the move, travelling between activist/epistemic communities.

Besides the seminars and workshops, these activists established publishing houses and co-operative bookshops, with 'Traficantes de Sueños' (Madrid) as the most remarkable example; elaborated and circulated their own texts, as well as texts from other groups; and developed militant research projects, counter-cartographies, etc. In this sense, the ODSs exercised what Holmes and Marcus have termed 'para-ethnography' (2008, p. 82), rich and critical registers, analysis, descriptions and explanations addressing both their own practices and the transformations affecting their social worlds. According to Nico, member of the network in Malaga, these knowledge-practices were crucial in allowing the activists 'to not talk about the crisis generically, to not talk about precarity generically, but to understand instead how they unfold and evolve in particular contexts' (interviewed 21 April 2010).

Thus, over the last decade, the same reflexive communities that created the ODSs also organized key initiatives in terms of activist research and knowledge production. Grassroots intellectual projects like 'Precarias a la Deriva,' 'Observatorio Metropolitano,' 'Nociones Comunes, 'Universidad Nómada' or 'Grupo de Estudios A Zofra', operated as movement institutions devoted to exercise the kind of para-ethnographic practices mentioned earlier. As an example, Mario, member of one of the ODSs located in Madrid, explained to me how they were carrying out a militant research project focused on the economic and political crisis erupted in 2008. At the time of our interview, the project had been running for more than two years, and it was about to be completed,

This process has been going on since late 2008. First, we did interviews about the crisis with different people. We recorded them on video and used those interviews to organize discussion workshops, and with the information gathered in the interviews and the workshops we started elaborating a manifesto about the crisis: people thinking the crisis. Then we organized new workshops to discuss the manifesto; we debated it within the different ODSs in the city, in the Spanish language classes we do with migrants, and in our own assemblies. Now we are planning to launch a final version in three or four months. All the methodology has been quite participatory; and it has been a very detailed and comprehensive process. Two years with the interviews, the editing work, the screenings and the discussion workshops, organizing new workshops to elaborate new versions of the manifesto ... it has been a very thorough process. Whatever we do must be thorough. (Interviewed June 9, 2010)

Rather than being an automatic reaction to external factors, collective action is the result of how activists make sense of those factors, how they understand and name what is going on through action-oriented analysis, leading to the development of concepts and tools that are tested in daily activism, and then collectively reassessed and modified. The fact that knowledge-practices were a constitutive dimension of the ODSs, and that I engaged with the network as a reflexive community, as epistemic partners generating their own expert knowledge, had profound implications for my project, which gradually shifted towards a collaborative undertaking.

\section{On research collaboration}

Collaboration means shifting from working on social movements to working and thinking together with social movement activists as co-researchers. Working with social movements requires considering research subjects as active agents of knowledge production, taking their epistemic and political locations, their questions and concerns, as well as their reflexivity and expertise - not solely academic interests or disciplinary considerations - as the departure point for research. The goal is to produce knowledge meaningful in scholarly terms, advancing our understanding of contemporary collective action, as well as relevant for the activist groups, so that they can use it as they see fit in the struggles they are involved in.

Collaborative frameworks allow researchers to move away from the mindset and practices of 'epistemic extractivism' (Grosfoguel, 2016) and towards a mindset and practices of reciprocity, critical 
dialogue and mutual learning in our connection to research subjects - thus contesting the epistemic violence caused by academia operating as an apparatus of capture of subaltern(ized) knowledges. In this sense, collaboration is not new. It is part of a larger genealogy in social sciences, a wide set of epistemic, theoretical and methodological traditions (participatory action research, feminist research, decolonial approaches, indigenous methodologies, activist research, etc.) which centrally address the politics of knowledge production, raising critical questions about what the purpose of research is, who is it relevant and useful for, how it is conducted, what knowledges we take seriously - whose knowledge counts - and for whom we write and how.

Problematizing the hierarchy of types of knowledge and knowledge producers does not imply the unconditional endorsement - the fetishizing - of all knowledge coming from social movements (Gillan, 2015). The aim is not to reverse the existing hierarchy but to articulate an 'ecology of knowledges' (Santos, 2014), a critical dialogue between different knowledges and knowledge producers - scholars and movement participants for the purpose of this article. Nevertheless, imposing its own sub-disciplinary questions and debates, the institutionalized field of social movement studies shows little interest in engaging in dialogue and joint explorations with social movement activists (Croteau, Hoynes, \& Ryan, 2005). Thus, it misses critical reflections and experimentations on the very nature of contemporary activism, led by activists themselves in the submerged networks of social movements that Melucci emphasized as a key site for the nurturing and transformation of collective action. As a result, a great deal of the theory produced by scholars 'converts activism into yet another deactivated intellectual product' (Greenwood, 2008, p. 333), being perceived as trivial and irrelevant by most movement participants.

Research collaboration is one tentative way out of this dead end. However, as I said before, rather than thinking about collaborative research as a programmatic ideal, we should address its complexities and hopes, limits and potentialities, making explicit how some undertakings go further than others in terms of the level of co-definition of the research process, how different projects combine more collaborative and more conventional moments, the techniques explored, the tensions generated by the often diverging expectations coming from both the academic field and the research subjects, ${ }^{5}$ or the multiplicity of forms in which collaboration is being shaped in real in-fieldwork encounters.

Collaborative research is a contextual praxis, not a normative one; it is an artisan, experimental, situated, slow, messy, creative and ethically driven engagement with the research subjects for the co-production of knowledge. Every project is unique, with its specific challenges and constrains; and collaboration can be articulated and implemented in many different ways. Furthermore, it is important to stress that not all topics or actors are suited for this type of methodology. Joanne Rappaport (2008) signalled three conditions as the basis for the articulation of research collaboration. First, there must be a relation of mutual trust between the actors, ${ }^{6}$ usually built through being rooted in an network, organization, community, etc. The second condition is the researcher's commitment to long-term dialogue, a demand that scholars cannot always meet; the slow pace of collaboration fits uneasily into the accelerated temporality of neoliberal academia. Finally, there must be a group of collaborators who can (and most important, who are willing to) take the lead in the co-analysis and co-theorizing process.

Sometimes, it is the extra-academic actors who seek for collaboration, offering the researcher to work together in a project. More often, however, it is the scholars who have a project and try to convince/seduce the research subjects to collaborate with them. In this case, collaboration will not be possible unless the actors we want to work with consider that getting involved in the project will benefit their own political praxis. The appropriation of the research on the part of the co-researchers, and its corresponding modification according to their own needs and interests, is the sine qua non of collaboration. In fact, the more the co-researchers appropriate the project - make the project theirs - the more useful it will become for them, by connecting with their own concerns and responding to their own questions. At the same time, the more they appropriate the project, the richer the co-analysis will be, allowing scholars to produce more complex and nuanced accounts of the topic under study.

For collaboration to progress, scholars must lose a significant share of control over the process of knowledge production. They need to unlearn well-established practices (and privileges) in order to 
be able to modify - in some cases, subordinate - their research plans, objectives and expectations to those of the co-researchers. In this sense, according to Holmes and Marcus, ethnography advances today, 'by risking collaborative encounters of uncertain outcomes for the production of ethnographic knowledge' (2008, p. 84) with highly reflexive subjects. This decentring move demands a particular attitude, an opening to vulnerability that might bring about novel possibilities for reflection and action.

\section{The collaborative turn}

In my research, the appropriation came about through a gesture that, however naïve it might seem now, proved to be crucial for the transformation of the project. The interviews developed across the network during the first phase of fieldwork were organized around four wide axes. One focused on the political coordinates/imagination of the Offices for Social Rights: Why had they been created? What was their goal? The second axis mapped the origin, characteristics and functioning of each individual node - the ODSs put to work. The third one examined the network as a whole, the relationship between the nodes, level of coordination and autonomy, mechanisms for decision-making, etc. Finally, the fourth axis concentrated on the interviewees' educational, professional and militant background. Being concerned about the relevance of my work for the activists, I included one last question in every interview: 'in your opinion, how could this research become useful for your project?'

I assembled the answers given to this question into two layers. One referred to the usefulness of the research outcomes, mainly the potential impact of its future publication. The other one related to the usefulness of the research taken as a process. Here, many participants underlined the immediate value of the interview itself as a moment of calm reflection within the daily urgencies of political militancy. Some suggested that I give all the raw materials produced during the project back to the network, so that they could use them as they saw fit. In this regard, we agreed that I would send the interviews' transcriptions back to the activists (each transcription was to be sent only to the actual interviewee) so that they could decide what to do with them. ${ }^{7}$ In some nodes, without me being involved at all, those materials were used in their own internal discussions and were functional for taking collective decisions; in addition, at least one activist incorporated some of the interviews into his own $\mathrm{PhD}$ project. And I imagine that they have been utilized in other ways that I do not know about.

Finally, other activists argued that the interviews ought to be used to trigger a collective discussion within the network. They said that the different ODSs needed to come together in order to review and redefine their work at a time (late 2010, more than two years into the economic, political, social and institutional crisis in Spain) when collective action was at a stalemate and social movements had been unable to articulate tangible responses.

Building upon this last proposal, in January 2011, I sent an email to the network asking the activists about the possibility of organizing several meetings or workshops, in which the research materials could be used as a departure point for a wider reflection on the ODSs. I suggested that in order to make such meetings as useful as possible, each node - or group of nodes - should define both the content to engage and the methodology of work. Also, I indicated that if they decided to go ahead I would put myself at their disposal, negotiating my role and my implication with them, so that I would accompany the process rather than leading it.

In mid-February 2011, the nodes decided to support the organization of a series of workshops, to be developed during the second half of the year, aimed at analysing the situation of the ODSs within the context of political impasse that I mentioned before. The activists emphasized the need to rethink their praxis; they wanted to debate the problems they were facing, as well as new insights and possibilities to move onward. Also, they considered that my interviews conveyed and systematized the reflections, concerns and expectations of members of all the ODSs in ways that were not available before. For this reason, each node was expected to engage with the interviews, using this material as a starting point for the discussion. This is how my project became integrated into the knowledge-practices of the network, a connection between my interests and theirs that eventually opened up the possibility for a 'collaborative turn'. Shortly afterwards, we started designing the second phase of fieldwork, the 
workshops that functioned as the principal settings in which the co-analysis, co-conceptualization and co-theorization (Rappaport, 2008) processes unfolded.

\section{The workshops (and the $15 \mathrm{M}$ earthquake)}

After much conversation, in early May 2011 we eventually arranged the dates for the first two workshops: one would take place in June, the other one in July, bringing together the four nodes of the network located in Madrid. However, much to everyone's surprise, less than a week later, on 15 May 2011, hundreds of thousands of people took to the streets and squares in Spain demanding 'Real democracy now!' and claiming that 'We are not goods in the hands of politicians and bankers'. These massive mobilizations gave rise to the so-called ' $15 \mathrm{M}$ Movement', the most important episode of grassroots collective action in the country in decades.

This unexpected event, and the subsequent opening up of a completely new political landscape - the dramatic end of the impasse - had an enormous impact on the network, as well as on the research. The unprecedented scale and intensity of the $15 \mathrm{M}$ overtook my study on the 'emerging' logics and practices of collective action. Many of the elements that I started analysing in 2008, focusing on a small network hardly worthy of attention under a more traditional understanding of social movement studies, became after May 2011 the distinctive features of collective action in Spain. The irruption of the $15 \mathrm{M}$ event/movement disorganized our plans. We decided to maintain the date for the first workshop, but its content shifted. The focus was no longer the analysis of the ODSs themselves but the collective reflection on the new scenario and its possibilities. Nevertheless, the network members agreed that it still made sense to use the interviews, since they considered that, although on an incomparable scale, the $15 \mathrm{M}$ largely embodied the ways of doing politics that they had been proposing and testing for the last decade. In this sense, the $15 \mathrm{M}$ 'disruption' actually deepened my research agenda.

The workshops design, and the negotiation around the various dimensions that needed to be addressed, including the role the activists expected me to play, differed according to the specific demands and characteristics of each node. Nevertheless, all of them were structured around two key dimensions. Firstly, the idea was to explore the connections, the continuities and discontinuities, between the new scenario and the political horizon, practices, hypothesis and debates that had informed the praxis of the network over the years, and here is where the interviews proved useful. Secondly, the goal was to reflect upon the necessary reinvention of this community of activism within the new context. Eventually, we developed and video-recorded six encounters: two day-long workshops with the nodes located in Madrid, in June and October 2011; two in Seville, in October 2011 and January 2012; one workshop for the nodes of Zaragoza and Pamplona in July 2011; and a last meeting in Terrassa in February 2012.

The first workshop in Madrid was entirely devoted to analysing the interviews. The goal was to examine the differences between what the activists expected to achieve when they created the ODSs, and what the ODSs had finally become. The metaphors that I mentioned before were discussed: the politics of the encounter, of listening, the artisan politics, the daily (re)production of the 'common' that sustains collective action, etc. Working initially in small groups, and then coming together for collective deliberation, the activists and I reviewed the interviews creating maps of concepts, practices, open possibilities, tensions and limits. These maps displayed the richness and the degree of political innovation of the ODSs, but also their frailty and the tensions and obstacles they encountered while implementing their ideas.

On the one hand, in relation to their initial (self)critique, the activists considered that they had succeeded in reaching beyond the boundaries of traditional activism, and that the network had created innovative political discourses and tools opposing the growing precaritization of life. Through their logic of experimentation, the search for openness and the politics of the encounter (the engagement with other actors beyond usual activist circuits), and the centrality of knowledge-practices and collective thinking (the 'asking, we walk'), the ODSs had made a significant contribution to the redefinition of grassroots politics in Spain. The members of the network complained that this process-oriented 
approach was maybe too slow, it took a lot of effort to actually see some results, but they agreed - and celebrated - that their insights had allowed them to imagine and experience a different way of doing politics.

On the other hand, most nodes of the network considered that they had failed in building the desired alliances between local and migrant communities against precarity. Unintentionally, the ODSs gradually specialized in working with 'undocumented' migrants; in fact, the network played a crucial role in the creation of the first organizations set up and led by 'illegal' migrants in Spain, an outstanding achievement. But the ODSs were unable to reach and mobilize the local precariat, which reduced their capacity to produce interventions of greater political impact. Within this context, the members of the network wondered if it was enough to simply change the tools and some strategies and practices, or was it actually the general coordinates - the political imagination and the collective analysis - that needed to be re-elaborated.

These discussions were the departure point for the second workshop, called 'Rethinking ourselves after the 15 M' (Repensarnos a partir del $15 \mathrm{M}$ ). Activists who had participated in the first encounter put together a working programme including methodology, facilitation and required logistics. The workshop was divided into two sessions. The first one, 'Where do we come from and how has the $15 \mathrm{M}$ changed us?' (¿De dónde venimos y cómo nos ha cambiado el 15 M?), was designed as a continuation of the debates from the first meeting. The second, 'What to do after the 15 M' (Y después del $15 \mathrm{M}$, ¿qué?), aimed at re-imagining the network and its practices in the post-15 M landscape. After similar debates in the other nodes, which depicted how the $15 \mathrm{M}$ and the new political landscape were being experienced by the activists, their expectations and concerns, three main areas of discussion emerged throughout the network. First, the new scenario closely resembled what the ODSs' activists had dreamed of for years but had failed to achieve. The $15 \mathrm{M}$ had indeed modified what was possible and thinkable. It had changed the collective mood - from the dense resignation of the impasse to the euphoria in the squares - and operated as a re-politicization machine. Practices that only a short time ago were exclusive of the repertories of action of activists, such as civil disobedience or non-violent direct action, had now become popularized, and were being deployed across the country by multiple actors within a strong cycle of pro-democracy and anti-austerity mobilizations. The new situation was extraordinary, and there was wide consensus that the network had to merge itself with the wave of contention unleashed by the $15 \mathrm{M}$, since it was there that political passion, intelligence and innovation were being articulated in unprecedented scale and intensity.

The second area of discussion was related to what the ODSs and the $15 \mathrm{M}$ shared. As I explained before, the $15 \mathrm{M}$ crystallized many of the ideas that this community of activism had tested over the last decade. However, the members of the ODSs were aware that the $15 \mathrm{M}$, having caught almost everyone by surprise, also highlighted the limitations of pre-existing social movements, including their own network. The 'local precariat' had eventually mobilized, but it happened outside and beyond - perhaps even as some activists put it, in spite of - social movements. Within this context, the ODSs had been pushed beyond their own limits, and it was necessary to revamp the experimental ethos that had characterized them over time. As Xavi, from the Terrassa node, claimed,

The $15 \mathrm{M}$-earthquake is right in front of our faces and the situation has shifted dramatically. There are things going on - without us being involved - that are gaining a magnitude and a strength that we could not even imagine. Then, what can we do? We must reconfigure the tools and join this wave and this process contributing the best that we have. ... When you do politics you build tools, machines that you believe might have an impact and provoke changes in a particular situation, and if they are not useful anymore then you have to rethink and redefine them, or you have to invent new ones that could work. (Workshop, February 2012)

In this sense, the overlap between my study and the $15 \mathrm{M}$ event/movement, also allowed me to map the continuities and discontinuities between cycles of mobilization. This question exceeds the scope of this paper; however, it is worth noting that, contrary to other works that emphasize continuity (Flesher Fominaya, 2014; Romanos, 2013; Zamponi \& Fernández González, 2017), what I found in my fieldwork - developed across the country within long-term activist communities before, during and after the eruption of the $15 \mathrm{M}$ - was that the activists perceived and expressed mostly discontinuity. 
In fact, as I said before, the $15 \mathrm{M}$ was often understood as a tacit critique to the 'ways of doing politics' of pre-existing social movement networks and organizations.

Finally, the third discussion revolved around those notions and practices that had been central to the ODSs but that were secondary in the $15 \mathrm{M}$. The common understanding was that the $15 \mathrm{M}$ was 'obscenely white', as Marta, an activist from Madrid, put it (interviewed, 12 June 2010). Along the same lines, Irene from Zaragoza argued:

The $15 \mathrm{M}$, the camps in the squares and everything else that happened around it, are also a reflection of how our city works. There are very few mixed spaces. There are some shops 'for Africans', call-centres 'for Latinos', streets 'for whites', bars and restaurants for such and such people. And for most migrants the $15 \mathrm{M}$ was considered as a 'white people's business' ... This is how everything works on a daily basis in Zaragoza; our city is divided, split, and so were the $15 \mathrm{M}$ mobilizations. After all it was a reflection of how borders work daily. This is how we usually live, and this was also what happened there. (Workshop, July 2011)

The fact that migrants were mostly absent in the mobilizations, and that the issues regarding migration and the border regime were largely unacknowledged, were a shared concern across the network. At the same time, challenging this shortcoming through the skills, the knowledge and the mestizo networks they had created over the years was perceived as the main (potential) contribution of the ODSs to the post-15 M scenario.

However, not all the workshops dealt with the same questions and problems. For collaboration to be useful, it must be adaptable; and the encounters that took place in Seville were quite different. This node shared with the rest of the network the concern about the capacity/incapacity of their tools to achieve the desired political goals. But what characterized this ODS at the time of the workshop was that it had serious difficulties in organizational terms, which threatened the continuity of the project. Within this context, the first workshop focused entirely on delimiting those internal problems; its main outcome was a collaboratively made map of the blockages affecting the ODS, to be used as a departure point for the discussions planned for the second encounter - which should lead to the collective redefinition of the project in terms of goals and organizational structure. The $15 \mathrm{M}$ played a more secondary role here. Also my role was quite different, since they expected me to intervene more than I had done in other points of the network, structuring and facilitating the debates in a more proactive and explicit manner. For the second workshop, the activists sent me a preliminary work programme including the objectives, content to be dealt with and methodology. They framed the encounter, and then invited me to facilitate the debates, which involved very sensitive topics (i.e. leadership roles, etc.). On the other hand, they expected me to link their discussions to the conversations that had taken place in other nodes, so that they could have a broader sense of the questions, problems and insights shared across the network.

To sum up, these collaborative spaces allowed me to explore my research topic with a much larger number of activists. The interviews were rich, but the workshops incorporated many other voices, adding new perspectives to the analysis. Besides, since the activists had been directly involved in this intellectual process - they had co-designed the workshops and co-produced the knowledge - there was no need to report back to them, the usual 'devolution' to the research subjects was redundant. Furthermore, it is worth emphasizing how, within this collaborative approach, I did not need to 'unveil' the limits and/or contradictions of the activists and their practices - an image that seems to obsess more traditional, allegedly critical scholars - for, as I have illustrated, the network members explicitly expressed and reflected upon them. This can be explained considering that in the workshops the activists were not responding to the figure of the researcher-as-expert; instead, they were talking and listening to their fellow activists and trying to elaborate together new possibilities for thought and action.

These workshops, driven by critical self-reflexivity and collective deliberation, were privileged sites to observe how the network members were putting their own world under the microscope, collectively rethinking their own ideas, categories and practices - the political metaphors that I have mentioned through this article - in order to re-signify and transform them. This is how these activists 
had determined a few years earlier that they needed to create the ODSs, and this is how they were trying now to adapt to the new political situation.

\section{Conclusion: on thinking together}

The co-analysis workshops described through the article, jointly designed and implemented with the members of the ODSs across the network, brought together the two axes shaping my research. On the one hand, the analytical role of activists, the methodological exploration and the unfolding of the (experimental) process of knowledge co-production; on the other hand, the ethnographic case study, the discussion on the transformation - the emerging logics and practices - of grassroots politics.

These workshops were spaces of collective reflexivity and deliberation. It was there that collaboration materialized; accompanying the activists and being accompanied by them, we destabilized the divide between informed expert and informant. It was there, also, where theory and praxis intertwined. I have explained how, in the second phase of fieldwork, the activists integrated their own questions, concerns and insights into the research design and implementation. They appropriated 'my' project by defining both the issues to be addressed and the methods to be used during the workshops. Besides, they grounded and enriched their discussions with the reflections previously collected in the research interviews, which fed the co-analysis process. In this way, my project contributed to the activists' knowledge-practices; this was the (limited but virtuous) input to the network members in their effort to transform their political praxis.

This contribution was developed during the research process itself. For the most part, I agree with Gillan and Pickerill (2012) when they warn scholars about the risks of turning what they call 'the ethic of immediate reciprocation' into a new dogma in social movement studies. However, I consider that they fail to acknowledge the many possibilities afforded by reciprocity, mostly within collaborative undertakings in which scholars and their collaborators negotiate the terms of 'reciprocation', defining the expected goals and outcomes of specific projects. Besides, Gillan and Pickerill seem to imply that analytical skills are the prerogative of academic researchers, a very problematic argument as I have explained through this article. Not all social movements should be thought of as producers of expert knowledge, but many contemporary organizations and networks, like the ODSs, operate today as reflexive communities engaged in cognitive praxis as a crucial dimension of their political action. The notions of activists as 'epistemic partners' and 'para-ethnographers', the image of 'following' the actors as they 'learn to name' their own innovations, the concept of 'knowledge-practices', and the metaphor of 'thinking together', capture this reality. Within this context, far from exerting the monopoly over expertise, complex analysis and interpretation, decentred scholars become facilitators, transducers, co-learners immersed in a crowded field of knowledge producers (Casas-Cortés, Osterweil, \& Powell, 2013, p. 199).

The appropriation of the research by the members of the ODSs - the 'collaborative turn', however partial - was the condition of possibility for the articulation of a project that was simultaneously productive at different levels. First, it advanced our understanding of contemporary collective action, providing an ethnographic account of the redefinition of grassroots political activism, the (dis)continuities between cycles of mobilization, and the way in which the $15 \mathrm{M}$ and its aftermath were perceived by long-term activists. Second, through its exploration of research collaboration, the project addressed salient epistemic and methodological debates in social science, specifically in relation to the ethics and politics of knowledge production. Finally, most important, this research proved relevant and useful for the activists-collaborators, the members of the ODSs, by connecting with their own aims, interests, concerns and knowledge-practices.

This is the goal and the challenge of collaborative research with social movements. Working and thinking together with the activists as co-researchers, taking seriously their epistemic and political locations, their reflexivity and expertise, brings about theoretical, epistemological and methodological innovation. At the same time, moving towards practices of reciprocity, engaging in sustained dialogue, negotiation, co-analysis and co-theorization, makes social science useful for the activists-collaborators. 
This is what a 'collaborative turn' can contribute to the field of social movement studies; a framework/ horizon that should be further explored if we aspire to expand the relevance of our work inside and outside academia.

\section{Notes}

1. The nodes were: Red de Apoyo a Sin Papeles de Zaragoza; Grupo de Migraciones y Precariedad - ODS de Pamplona/Iruña; ODS EXIT - Barcelona; ODS de Terrassa - Ateneu Candela; ODS de Málaga - Centro Social y Cultural de Gestión Ciudadana 'La Casa Invisible'; ODS de Sevilla - Centro Vecinal Pumarejo; finally, in Madrid, ODS del Patio Maravillas, ODS de Carabanchel, ODS del Centro Social Seco, and Asociación de Sin Papeles de Madrid.

2. For further information on the network, the Thesis is available (in Spanish) at the University of Granada's institutional repository: http://hdl.handle.net/10481/34050.

3. All the activists' names in the article are real. This point was discussed and agreed during the research project.

4. Some of these elements can be considered as common features of autonomous social movements in Spain (Flesher Fominaya, 2014). However, what was distinctive, both in the ODSs and in the $15 \mathrm{M}$, was the strong critique/ problematization of pre-existing social movements, the emphasis on the need to 'exit' traditional activists' circuits, practices, languages, etc. in order to redefine grassroots politics; as well as the post-ideological dimension, the search for heterogeneity, the challenge of learning to work together politically while being 'different'.

5. I had no relevant tensions with the activists during the project. My main concern related to academic logic and procedures: I could not stretch research collaboration into the writing process because, at least in Spain, the $\mathrm{PhD}$ dissertation must be single-authored - a gesture that in this case denied the very nature of the process of knowledge production.

6. Back in time I was part of the activist community I studied in my research. Then I moved abroad for several years and I stopped being organically tied to the network. When I returned to Spain and began this project, those nodes and activists that had joined the network while I was away did not know me; but for many others I was a close friend and a former fellow activist. I was never part of an ODS; however, the fact that the ODSs were created within the activist communities in which I had been rooted for many years somehow made me, simultaneously, an insider and an outsider to the network, and this location was a key element in my research.

7. When I devolved the transcriptions I gave each activist the option to revise his/her interview and send me a final version to be used for the project. Only two, out of thirty-one, were modified, and in one of those the changes affected simply style and edition, not the content of the discourses.

\section{Disclosure statement}

No potential conflict of interest was reported by the author.

\section{Notes on contributor}

Alberto Arribas Lozano, PhD in Applied Social Sciences, is a current postdoctoral fellow in Research and Social Justice at SWOP Institute, University of the Witwatersrand, Johannesburg, South Africa. He is also an associate researcher within the project: 'Procesos emergentes y agencias del común: praxis de la investigación social colaborativa y nuevas formas de subjetivación política', funded by the Spanish National Plan for Scientific and Technical Research and Innovation (Ref.: CSO2014-56960-P), at the University of Granada (Spain).

\section{References}

Arribas Lozano, A. (2015). Recordar el 15 M para reimaginar el presente. Los movimientos sociales en España más allá del ciclo electoral de 2015 [Remembering the ' 15 M' to re-imagine the present. Collective action in Spain beyond the 2015 elections]. Interface: A Journal for and About Social Movements, 7(1), 150-164.

Arribas Lozano, A. (2018). Reframing the public sociology debate: Towards collaborative and decolonial praxis. Current Sociology, 66(1), 92-109.

Casas-Cortés, M. I., Osterweil, M., \& Powell, D. (2008). Blurring boundaries: Recognizing knowledge-practices in the study of social movements. Anthropological Quarterly, 81(1), 17-58.

Casas-Cortés, M. I., Osterweil, M., \& Powell, D. (2013). Transformations in engaged ethnography: Knowledge, networks, and social movements. In J. S. Juris \& A. Khasnabish (Eds.), Insurgency encounters: Transnational activism, ethnography, and the political (pp. 199-228). Durham, NC: Duke University Press. 
Cox, L. (2014). Movements making knowledge: A new wave of inspiration for sociology? Sociology, 48(5), 954-971.

Croteau, D., Hoynes, W., \& Ryan, C. (Eds.). (2005). Rhyming hope and history: Activists, academics and social movement scholarship. Minneapolis, MN: University of Minnesota Press.

Eyerman, R., \& Jamison, A. (1991). Social movements: A cognitive approach. University Park: Pennsylvania State University Press.

Flesher Fominaya, C. (2014). Debunking spontaneity: Spain's 15-M/Indignados as autonomous movement. Social Movement Studies, 14(2), 142-163.

Foucault, M. (1983). Preface. In G. Deleuze \& F. Guattari (Eds.), Anti-oedipus (pp. xi-xiv). Minneapolis, MN: University of Minnesota Press.

Gillan, K. (2015). Towards an ethic of public sociology. Discover Society, 16. Retrieved from http://discoversociety. org/2015/01/03/towards-an-ethic-of-public-sociology/

Gillan, K., \& Pickerill, J. (2012). The difficult and hopeful ethics of research on, and with, social movements. Social Movement Studies, 11(2), 133-143.

Greenwood, D. (2008). Theoretical research, applied research, and action research. The deinstitutionalization of activist research. In C. R. Hale (Ed.), Engaging contradictions: Theory, politics, and methods of activist scholarship (pp. 319-340). Berkeley: University of California Press.

Grosfoguel, R. (2016). Del «extractivismo económico» al «extractivismo epistémico» y al «extractivismo ontológico»: Una forma destructiva de conocer, ser y estar en el mundo [Between economic extractivism and epistemic/ontologic extractivism: A destructive way of being in the world and of knowing the world]. Tabula Rasa, 24, 123-143.

Holmes, D. R., \& Marcus, G. E. (2008). Collaboration today and the re-imagination of the classic scene of fieldwork encounter. Collaborative Anthropologies, 1, 81-101.

Lassiter, L. E. (2005). The Chicago guide to collaborative ethnography. Chicago, IL: University of Chicago Press.

Latour, B. (2005). Reassembling the social. An introduction to actor-network-theory. Oxford: Oxford University Press.

Melucci, A. (1989). Nomads of the present. Social movements and individual needs in contemporary society. London: Hutchinson.

Rappaport, J. (2008). Beyond participant observation: Collaborative ethnography as theoretical innovation. Collaborative Anthropologies, 1, 1-31.

Romanos, E. (2013). Collective learning processes within social movements: Some insights into the Spanish $15 \mathrm{M}$ movement. In L. Cox \& C. Flesher Fominaya (Eds.), Understanding European movements (pp. 203-219). London: Routledge.

Santos, B. S. (2014). Epistemologies of the South: Justice against epistemicide. New York, NY: Routledge.

Villasante, T. R. (2012). Construir Acción-Conocimientos Colectivos. ¿Desde dónde? ¿Para quién? ¿Por qué? ¿Para qué? [Building collective knowledge and action]. In A. Arribas, N. García-González, A. Álvarez, \& A. Ortega (Eds.), Tentativas, contagios, desbordes. Territorios del pensamiento (pp. 187-221). Granada: Editorial UGR.

Zamponi, L., \& Fernández González, J. (2017). Dissenting youth: How student and youth struggles helped shape antiausterity mobilisations in Southern Europe. Social Movement Studies, 16(1), 64-81. 